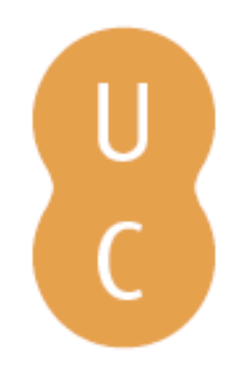

\title{
pommalina
}

\section{Cidade do saber/cidade do poder: a arquitetura da reforma}

\author{
Autor(es): $\quad$ Pimentel, António Filipe
}

Publicado por: Imprensa da Universidade de Coimbra

URL

persistente: URI:http://hdl.handle.net/10316.2/31953

DOI: $\quad$ DOI:http://dx.doi.org/10.14195/978-989-26-0753-5_8

Accessed : $\quad$ 26-Apr-2023 16:32:57

A navegação consulta e descarregamento dos títulos inseridos nas Bibliotecas Digitais UC Digitalis, UC Pombalina e UC Impactum, pressupõem a aceitação plena e sem reservas dos Termos e Condições de Uso destas Bibliotecas Digitais, disponíveis em https://digitalis.uc.pt/pt-pt/termos.

Conforme exposto nos referidos Termos e Condições de Uso, o descarregamento de títulos de acesso restrito requer uma licença válida de autorização devendo o utilizador aceder ao(s) documento(s) a partir de um endereço de IP da instituição detentora da supramencionada licença.

Ao utilizador é apenas permitido o descarregamento para uso pessoal, pelo que o emprego do(s) título(s) descarregado(s) para outro fim, designadamente comercial, carece de autorização do respetivo autor ou editor da obra.

Na medida em que todas as obras da UC Digitalis se encontram protegidas pelo Código do Direito de Autor e Direitos Conexos e demais legislação aplicável, toda a cópia, parcial ou total, deste documento, nos casos em que é legalmente admitida, deverá conter ou fazer-se acompanhar por este aviso.

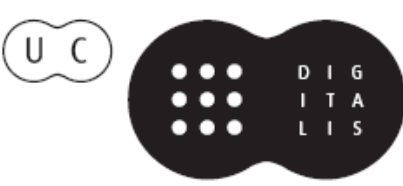



(Página deixada propositadamente em branco) 
CIDADE DO SABER/CIDADE DO PODER A ARQUITECTURA DA REFORMA

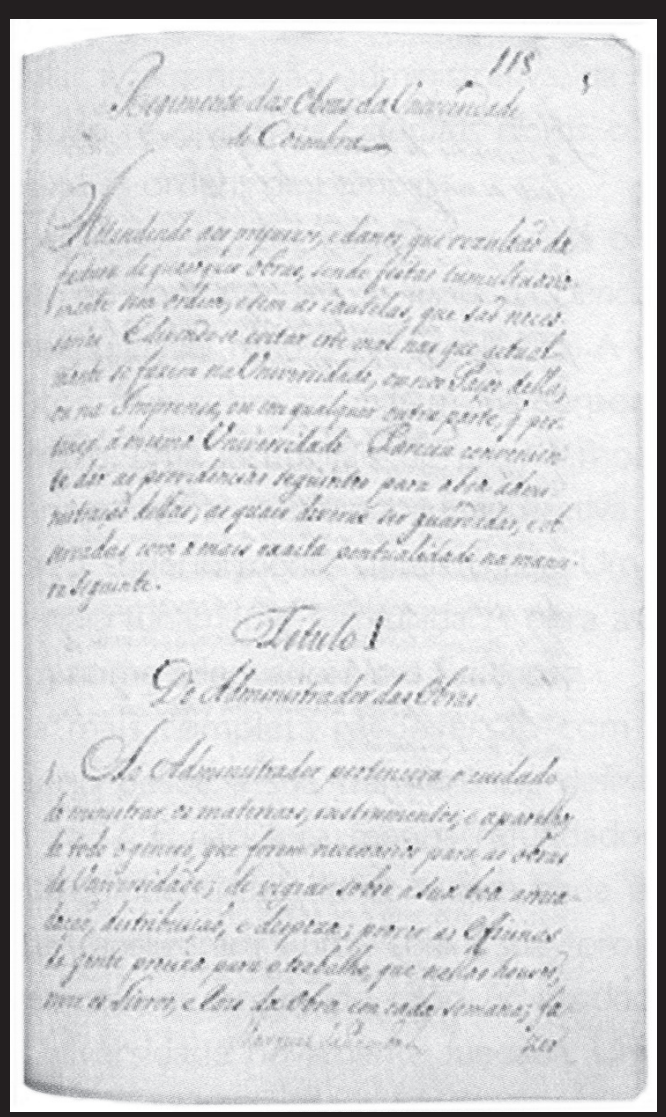


Regimento das Obras da Universidade de Coimbra, 1772, Arquivo da Universidade de Coimbra

foto: Varela Pècurto 


\section{CIDADE DO SABER/CIDADE DO PODER} A ARQUITECTURA DA REFORMA

No verão de 1772, a Reforma, que a publicação, no ano anterior, do Compêndio Histórico do Estado da Universidade de Coimbra prenunciara, abatia-se, por fim, sobre o velho arcaboiço da secular instituição. Da base ao cimo, da estrutura curricular à organização administrativa, da vida económica aos ritos e cerimoniais, tudo revolviam os Estatutos Novos, concebidos pela Junta da Providência Literária às ordens de Pombal.

$\mathrm{Na}$ mente do legislador, porém, não se tratava já de corrigir abusos ou antigos vícios; sequer de abrir, por fim, às luzes da ciência as portas do que fora até então o inexpugnável reduto da Escolástica. A drástica intervenção tinha por finalidade construir, sobre a antiga malha corporativa de imunidades e privilégios imemoriais, uma instituição de ensino moderna e esclarecida, desde logo mas, principalmente, submissa administrativa e pedagogicamente à estratégia de Estado superiormente determinada. Uma Universidade Real, na hábil designação oportunamente formulada. A obra assim delineada tinha, por isso, também, um nome adequado: Nova Fundação.

Era, de facto, a mais completa reconversão com que se defrontara o claustro universitário desde a sua transferência definitiva para Coimbra, por D. João III, em 1537. E não fora menos refundadora, todavia, em seu tempo, essa derrota quinhentista que do quase nada erguera uma escola ilustre e para sempre transfigurara a urbe com a sua coroa orgulhosa de colégios. Agora, uma vez mais se erguia do chão uma cidade do saber,

\footnotetext{
${ }^{*}$ Faculdade de Letras da Universidade de Coimbra.
} 
enquadrando a vida da Universidade novamente fundada. Uma cidade que seria a morada da razão, que havia norteado o programa redentor; que constituiria a nova imagem que a universidade nova para si cunhava. Somente não poderia já brotar, como essa outra, rasgando em dom pacífico a teia tortuosa das ruas mediévicas. A nova cidade haveria de erguer-se contra a cidade velha que a velha universidade dominara. Seria a cidade dos vencedores levantada sobre o espólio dos vencidos. E é esse selo incontornável, afinal, que a converte também e, sobretudo, na cidade do poder.

Apesar disso, a investida pombalina não caíra de chofre sobre o bastião do aristotelismo. Nem a denúncia do obscurantismo escolástico e jesuítico que obstinadamente havia defendido, tivera de esperar pelo Compêndio Histórico. O cerco à instituição sobre a qual pousava o ónus de formar os quadros superiores do Reino, fora gizado meio século atrás, como corolário natural do processo geral de penetração das luzes e de renovação cultural e científica do País que forma o pano de fundo do reinado (e da actuação) de D. João V. E é também então que a Universidade assiste, pela primeira vez, à imposição, no seu recinto, de uma arquitectura de poder. Nesse primeiro assalto, pois, gorado embora, reside a matéria genética do processo que teria, afinal, no arremesso letal de 72 , tão somente a derradeira batalha.

De facto, a partir de 1717 , tinha início a contrução, no terreiro universitário, adjacente à antiga Capela Real, da nova Livraria: a Biblioteca Joanina, como ficaria conhecida. O esplêndido edifício, que viria a converter-se no mais sumptuoso ornato do Paço das Escolas, respondia a um pedido do reitor, Nuno da Silva Teles (II), o qual, em virtude da ruína e má localização da que, no complexo dos Gerais, concebera o seu predecessor homónimo em finais do século anterior, se dirige ao Rei, expondo não ter a Universidade "caza competente para huma boa livraria"1. Por "boa livraria” aludiria o prelado, certamente, às condições físicas do local -

${ }^{1}$ Cfr. Francisco Carneiro de Figueiroa, Memórias da Universidade de Coimbra, Coimbra, 1937, p. 161. 


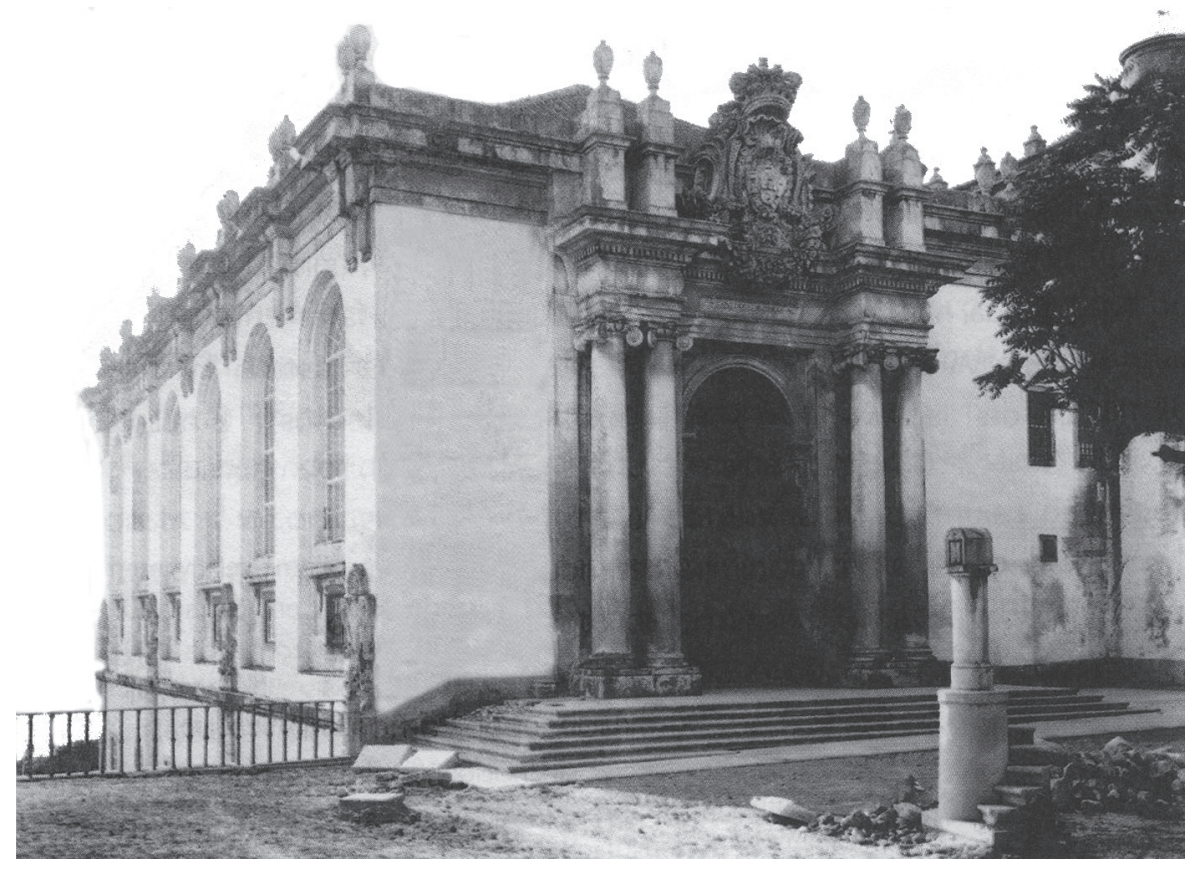

Vista geral do exterior da Biblioteca Joanina antes da intervenção realizada pelos Monumentos Nacionais na década de 30

(foto: arquivo fotográfico Direcção Geral dos Edifícios e Monumentos Nacionais) 
espaço, luz, salubridade -, diminuto como era o volume de livros existente ${ }^{2}$. Num tal contexto, pois, a "casa competente" mais não seria, na verdade, que uma dependência apropriada (que o não era, efectivamente, a velha "Livraria", virada a Norte, entalada entre a Sala Grande e o geral da Matemática) obtida pela reconversão, para esse fim, de um dos espaços existentes. Supreendentemente, porém, a provisão régia que autorizava o empreendimento, datada de 31 de Outubro de 1716, extrapolava os limites modestos sugeridos por Silva Teles e à "casa competente" contrapunha a construção, em "lugar conveniente" do pátio das Escolas, de "fábrica adequada" erguida de raíz. Do mesmo passo, determinava a compra em sua intenção de uma biblioteca particular³.

Por este modo, pois, escapava ao controlo da velha instituição de ensino o processo construtivo da nova Livraria, convertida em pólo angular de um quadrilátero de grandes núcleos bibliográficos de responsabilidade régia (com a Livraria Real e as de Mafra e das Necessidades) ideados como agentes dinamizadores da renovação das estruturas culturais ${ }^{4}$. Na súbita liberalidade do monarca, com efeito, mais não fazia que ocultar-se o propósito de, por intermédio da nova biblioteca, promover a renovação do ensino ministrado na secular instituição. Concluída a construção, em $1728^{5}$, tinha assim inicio essa outra empresa, não menos vultuosa, que consistia em fazer entrar, num claustro que acabava de condenar solenemente os erros de Pascal', "livros de Philosophia, e de Medicina,

\footnotetext{
${ }^{2}$ Efectivamente, a recolha no Cartório universitário dos livros da biblioteca, em 1705, em consequência da ruína desta (J. Ramos Bandeira, Universidade de Coimbra. Edifícios do Corpo Central e Casa dos Melos, Coimbra, 1943, tomo I, p. 252) sugere um volume relativamente diminuto, confirmado, de resto, pelo cardeal da Mota, já em 1729, quando afirma, em carta a D. Luís da Cunha, que na nova Casa da Livraria apenas existia "hum pequeno corpo de AA. Juristas" (Biblioteca da Academia das Ciências de Lisboa, Ms. 592 Azul, fl.408). Sobre os espaços ocupados pela livraria universitária veja-se António Filipe Pimentel, "A Biblioteca da Universidade e os seus espaços", Tesouros da Biblioteca Geral da Universidade de Coimbra, Coimbra, Imprensa da Universidade de Coimbra, 2011.

3 Cfr. A. da Rocha Madahil, "Biblioteca da Universidade de Coimbra", Grande Enciclopédia Portuguesa-Brasileira, Lisboa - Rio de Janeiro, Editorial Enciclopédia [s.d.], vol. IV, p. 625.

${ }^{4}$ Cfr. António Filipe Pimentel, "Uma empresa esclarecida: a Biblioteca Joanina", Monumentos, $\mathrm{n}^{\circ}$ 8, Lisboa, 1998, pp. 49-50.

5 Veja-se Pedro Ferrão, "A construção da Casa da Livraria da Universidade de Coimbra", Actas do Colóquio A Universidade e a Arte, 1290-1990, Coimbra, Instituto de História da Arte, 1993, pp. 85-120.

${ }^{6}$ Manuel Augusto Rodrigues, A Universidade de Coimbra e os seus Reitores: para uma história da instituição, Coimbra, Arquivo da Universidade, 1990, pp. 133-134.
} 
especialm. ${ }^{\text {te }}$ dos sistemas modernos"7. E nesse trabalho ingente se iriam absorver, nos anos que se seguem, alguns dos mais destacados protagonistas das luzes joaninas, como o cardeal da Mota, D. Luís da Cunha, o conde da Ericeira ou os médicos judeus Jacob de Castro Sarmento e António Nunes Ribeiro Sanches.

Globalmente inglório como, de facto, seria, ante o muro obstinado da resistência universitária, nem por isso deixaria de introduzir na cidadela do aristotelismo, a meio século de distância, os manuais pombalinos da Reforma ${ }^{8}$. Com ele, porém, se entrecruza outro desígnio, em paralelo acalentado e à luz do qual o empreendimento da Livraria adquire o seu real sentido: o da reforma do ensino médico, tudo indica que entendida como plataforma de assalto às restantes áreas científicas, em que se trabalha a partir da década de 30 . Por detrás do pano, movem-se uma vez mais as personagens evocadas?.

Desse longo e persistente cerco, feito de avanços e recuos, quedariam testemunhos dispersos, como o microscópio que Sarmento ofereceu à Universidade em $1731^{10}$ ou o plano para um Jardim Botânico que, no mesmo ano, enviou em luxuosa gravura dedicada ao reitor Francisco Carneiro de Figueiroa11. Mas a sua evocação não seria esquecida no Compêndio

7 Cfr. a referida carta do cardeal da Mota a D. Luís da Cunha, de 01.09.1729, onde se alude à ordem que D. João $\mathrm{V}$ dera ao reformador da Universidade para que disponibilizasse dinheiro para a compra de livros nos termos referidos. Sobre este assunto veja-se ainda José Sebastião da Silva Dias, "Portugal e a Cultura Europeia (séculos XVI a XVIII)", Biblos, vol. XXVIII, Coimbra, 1952, nota P, pp. 476-479, que primeiro deu a conhecer essa correspondência, de vital importância para a história da frustrada (mas determinante) "reforma joanina" da Universidade.

8 Cfr. Idem, ibidem, p. 479.

9 Cfr. Hernâni Cidade, Licões de Cultura e Literatura Portuguesas, Coimbra, Coimbra Editora, vol. II, 1942, pp. 42-43; António Alberto Banha de Andrade, Verney e a filosofia portuguesa, Braga, Cruz, 1946, p. 220 e António Braz Teixeira, O pensamento filosófico-jurídico português, Lisboa, Instituto de Cultura e Língua Portuguesa, 1983 (Biblioteca Breve), p. 36. Veja-se também Teophilo Braga, Dom Francisco de Lemos e a Reforma da Universidade de Coimbra, Lisboa, Academia Real das Sciencias, 1894, pp. XXVIII-XXXI.

10 Veja-se Angela Delaforce, (coord. de), Portugal e o Reino Unido; a Aliança Revisitada, Lisboa, Fundação Calouste Gulbenkian, 1994, p. 180 e O Engenho e a Arte, colecção de Instrumentos do Real Gabinete de Física, Coimbra-Lisboa, Museu de Física da Universidade de Coimbra/Fundação Calouste Gulbenkian, 1997, p. 312.

11 Cfr. Portugal no Século XVIII: de D. João V è Revolução Francesa, Lisboa, Biblioteca Nacional, 1989, Cat., p. 48 e est. 110. Desta gravura existe cópia na Biblioteca Geral da Universidade de Coimbra, incluída no Ms. 3180. 
Histórico ${ }^{12}$ e, já em 63, é ainda nesse âmbito que Ribeiro Sanches elabora o seu Metodo para aprender a estudar a Medicina; a ele se apensaria, afinal, o texto que constitui a consagração teórica da estratégia de há muito delineada pela Coroa - os Apontamentos para estabelecer-se huma Universidade Real, na qual deviam apprender-se as Sciencias humanas, de que necessita o Estado civil e politico ${ }^{13}$.

O estabelecimento da Universidade Real teria, é certo, de aguardar uma década mais; mas a Biblioteca Régia constituia já um marco incontornável, irrompendo, com a estridência de uma ingerência cortesã, no longo prospecto do Paço das Escolas, vincado ainda das campanhas quinhentistas. Significativamente, no alçado principal, deliberadamente moldado de um arco de triunfo, a imagem da Sabedoria, cunho tradicional das empresas universitárias ${ }^{14}$, cedia o passo ao opulento escudo régio que avulta, pletórico, com a eloquência de um sinal de posse; no interior, tudo se congraça numa teofania do poder real.

Não era, porém, gratuita a liturgia: a apoteose do monarca, minuciosamente codificada no programa iconográfico e reforçada pelo efeito sumptuoso da decoração ${ }^{15}$, decorre aqui do seu projecto esclarecido. E se o triunfo do saber se veste do esplendor do príncipe é por ser daí que lhe vem a força - força, na verdade, sem a qual não teria sido possível fazer entrar no alcácer do conservadorismo os livros que falavam dos sistemas modernos.

12 Veja-se Compêndio Histórico do Estado da Universidade de Coimbra, Coimbra, Por Ordem da Universidade, 1972, pp. 344-348.

13 Dessa obra raríssima, como continuamente referem os autores que se debruçaram sobre a questão (cfr. Teóphilo Braga, ob. cit., p.p. XXX-XXXI), localizámos dois exemplares, um na Biblioteca Nacional, com a cota S.A. 29995 P, outro na Biblioteca Pública Municipal do Porto, com a cota RJ-710.

${ }^{14}$ Efectivamente, os Estatutos Velhos estipulavam expressamente que a insígnia universitária se aplicasse a tôdas as fábricas, peças de prata, ornamentos ricos, E mais obras, E liuros (cfr. A. G. da Rocha Madahil, "A Insígnia da Universidade de Coimbra. Esbôço histórico", O Instituto, Coimbra, vol. 92, I Parte, 1937, p. 433 e, para o cumprimento deste preceito nas campanhas arquitectónicas universitárias, António Filipe Pimentel, "Domus Sapientice, o Paço das Escolas”, Monumentos, n 8, Lisboa, 1998, pp. 35-39).

15 Veja-se António Filipe Pimentel, "O gosto oriental na obra das estantes da Casa da Livraria da Universidade de Coimbra”, Portugal e Espanha entre a Europa e Além-Mar, Coimbra,[s.n.], 1988, pp. 347-368 e "Uma empresa esclarecida: a Biblioteca Joanina", pp. 50-51. 


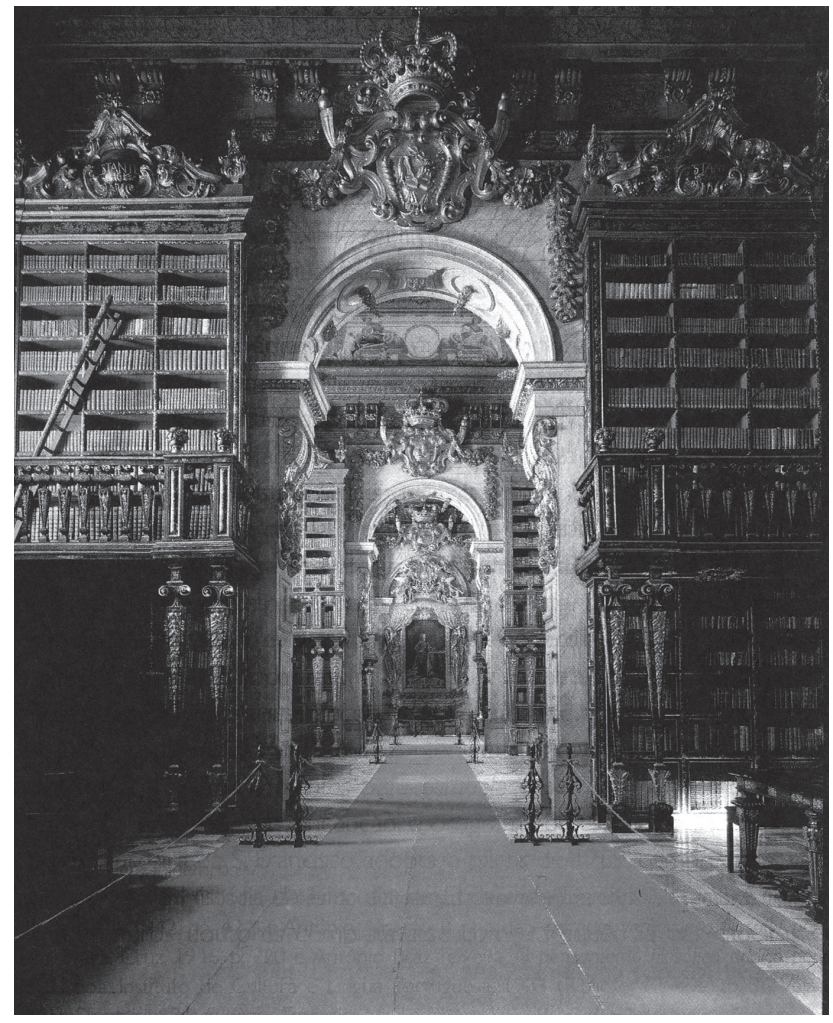

Perspectiva interna da Biblioteca Joanina

(arquivo fotográfico Direcção Geral dos Edifícios e Monumentos Nacionais) 
Com a construção da Livraria, pode dizer-se que a Universidade experimentara, pela primeira vez em muito tempo, o peso do poder real. Se a Coroa não triunfara propriamente no seu intento reformista, não deixara de abrir, mesmo ao nível visual, uma brecha irreparável na muralha corporativa da orgulhosa instituição. Entre a animadversão estatal e a crescente pressão das vozes críticas, a velha escola, onde a expulsão da Companbia, em 59, não deixaria de repercutir-se como um mau agoiro, a pouco e pouco se capacitaria, afinal, da inexorabilidade da Reforma. Esta rendição antecipada, justificativa da cordura com que o claustro acata a tormenta legislativa de 72 estará, porventura, na origem do programa diplomático que constituiria a erecção, em finais da década de $50^{16}$, do excelente arranjo cenográfico da Via Latina, concebido como monumento a D. José I. Empreendimento universitário, retoma, na figura acroterial da Sapiência, coroando o grande pórtico central, a antiga tradição simbólica; mas o escudo régio avulta uma vez mais, dominando o centro do frontão, numa praxis que a Biblioteca inaugurara enquanto, sob a tripla arcada, o busto do monarca se destaca entre alegorias oportunas à fortaleza e à justiça.

Deste modo, quando a Reforma, enfim, ecoa pelos Gerais, sacudindo, desde os alicerces, as velhas estruturas, a Universidade, com exemplar sabedoria, podia ostentar já, em pleno curso, o seu próprio processo redentor. De facto, se o monumento ao Rei Reformador inquestionavelmente dava coerência arquitectónica e dignidade à praça que empiricamente se formara no interior do recinto fortificado medievo ${ }^{17}$, sobretudo reforçava, de modo explicito, a sua natureza de Universidade Real, sem contradição, de resto, numa escola que (em outro sentido) sempre disso mesmo se

${ }^{16}$ Estamos hoje em condições de rever a cronologia (mais tardia) que propuzemos para a emblemática colunata no nosso trabalho já referido "Domus Sapientice, o Paço das Escolas". Reservamos, porém, a informação completa sobre a sua construção para a $2^{\mathrm{a}}$ parte da obra que constituiu a nossa dissertação de doutoramento A Morada da Sabedoria I. O Paço Real de Coimbra: das origens ao estabelecimento da Universidade (Coimbra, Almedina, 2003).

17 Cfr. António Filipe Pimentel, ibidem, pp. 38-39. 

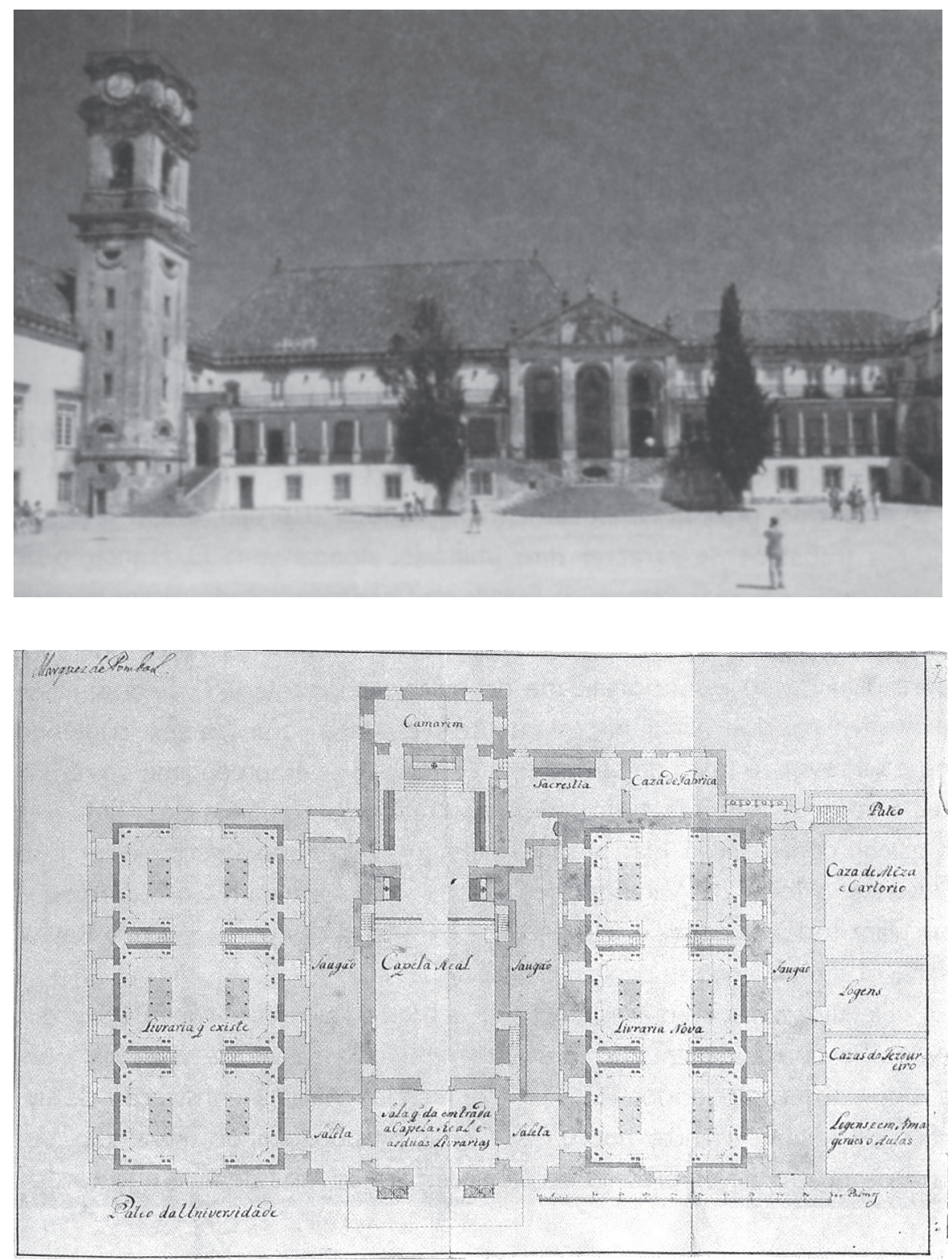

\section{Vista Geral da Via Latina \\ (foto: Varela Pècurto)}

Guilherme Elsden, planta do projectado sistema de Capela e Bibliotecas (Museu Nacional de Machado de Castro, foto: José Pessoa, Divisão de Documentação Fotográfica do IPM) 
ufanara ${ }^{18}$. Assim, pois, reabilitado já, por antecipação embora, o secular cenário do obscurantismo, ideologicamente adaptado ao contexto da nova fundação, podia o reitor Lemos arrogar-se a liberdade de suspender, a seu arbítrio, o projecto concebido pelo Marquês de transfiguração da ala ocidental do palácio universitário pela construção de uma nova capela e biblioteca que, desta feita, se destinava a promover a apoteose josefina ${ }^{19}$.

Emblemático edifício, esse, de resto, de uma arquitectura de poder. Riscado por Guilherme Elsden - o inglês que Pombal desviara das obras da reconstrução de Lisboa como tracista das arquitecturas da Reforma ${ }^{20}$ - num classicismo seco, ao jeito dos novos prédios de rendimento da baixa, unia, num vestíbulo comum, o novo templo e as duas bibliotecas (velha e nova) que, eloquentemente, o comprimiam. Exteriormente, de resto, referência alguma aludia à presença da Capela no interior do complexo biblio-religioso, ao mesmo tempo que a completa ausência, no severo portal, de qualquer componente simbólica - o escudo real, que não, evidentemente, a Sapiência (uma tarja moldurada, tão somente, deveria receber a competente inscrição fundacional) - denota bem que o monumento régio da Via Latina fora já integrado na lógica reformada do prospecto do velho Paço.

Preterido, pois, pragmaticamente, o simbólico projecto, em favor de outros trabalhos de caracter dito utilitário, alongar-se-ia D. Francisco de Lemos, na sua famosa Relação do Estado da Universidade, redigida em hora de justificações, na descrição de serventias e melhoramentos vários operados para dignificação e funcionalidade do palácio universitário ${ }^{21}$. É, pois, nesse exaustivo rol que, afinal, discretamente passa, sem que lhe seja conferido especial revelo, o rasto de um dos mais significativos

18 Cfr. Idem, ibidem, pp. 35-39.

19 Veja-se Mariana Mora, "Os projectos de remodelação do Paço das Escolas ao tempo da Reforma Pombalina”, Actas do Colóquio A Universidade e a Arte, 1290-1990, Coimbra, Instituto de História da Arte, 1993, pp. 137-141.

20 Veja-se Maria de Lurdes Craveiro, "Guilherme Elsden e a introdução do neoclassicismo em Portugal”, Portugal e Espanha entre a Europa e Além-Mar, Coimbra, Instituto de História da Arte, 1988, pp. 504-508.

21 Cfr. Francisco de Lemos, Relação Geral do Estado da Universidade (1777), Coimbra, Por Ordem da Universidade, 1980, pp. 135-138 (152-154). 

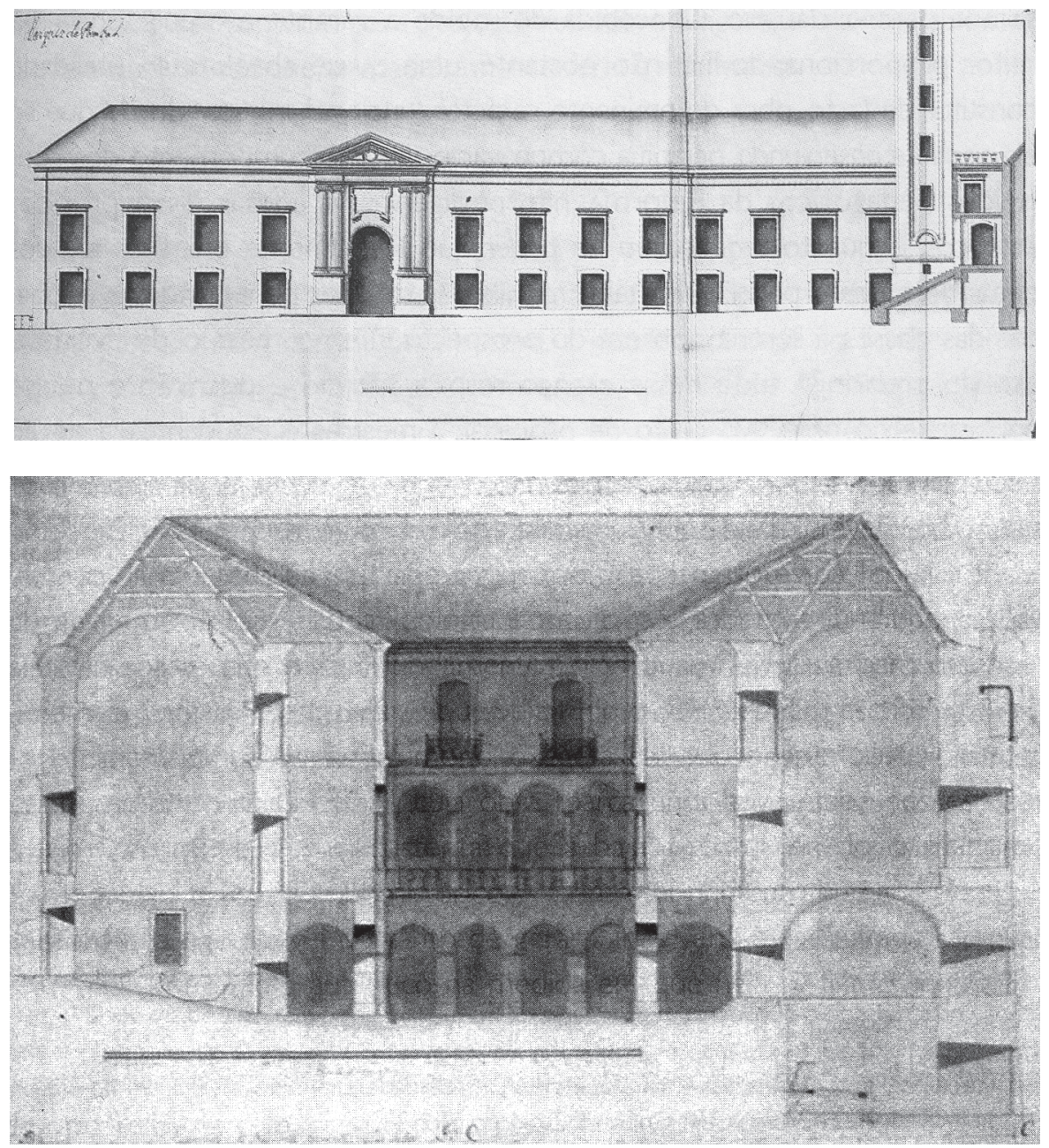

Guilherme Elsden, projecto para a reforma do alçado poente do Paço das Escolas (Museu Nacional de Machado de Castro, foto: José Pessoa, Divisão de Documentação Fotográfica do IPM)

Manuel Alves Macomboa (?), Corte dos Gerais e Galeria de Circulação (Observatório Astronómico da Universidade de Coimbra, foto:Varela Pècurto) 
empreendimentos arquitectónicos da Reforma, tudo indica que realizado nos anos de 1773-7422: a galeria de circulação. Nas próprias palavras do prelado, refere ele ter feito "levantar o tecto das Varandas dos Geraes; e se formaram Corredores, que circulam todas as Aulas, e dão Tribunas para ellas; das quaes pode o Reytor ver, e observar, o que se passa nas ditas Aulas"23.

Efectivamente, com acesso a partir do Paço Reitoral, através da Sala dos Actos Privados, organiza o reformador-reitor uma galeria de vigilância a um tempo sobre os períodos lectivo e de recreio, graças à construção de um novo piso sobre o andar nobre dos Gerais, proporcionando um amplo passeio de quatro naves, provido de tribunas para as salas de aula e janelas de sacada para o claustro. Concebida de molde a garantir a omnisciência do reitor, proporcionando-lhe, não obstante, uma quase absoluta invisibilidade, constitui, de facto, obra de eminente carácter funcional, no sentido de que só ela, vendo e observando, permitia comprovar o efectivo cumprimento dos conteúdos pedagógicos da Reforma; não negligenciaria, apesar disso, pruridos estéticos, enquanto arquitectura de poder que lidimamente era. Dos alçados deitando sobre o pátio, à rica talha rocaille das tribunas penetrando as abóbadas das classes, à serena nobreza do prospecto interno, mesmo, de exclusivo uso do prelado $^{24}$, tudo nesse espaço respira silêncio e discrição e parece conluiar-se no objectivo único de propiciar, a mestres e estudantes, a noção física de um poder omnipresente, materializado no reitor e na sua pessoa, sempre suspeitada, nunca confirmada.

Arquitectura da Reforma e eminentemente, a galeria de circulação é, contudo, mais especificamente ainda, arquitectura do reitor Lemos. É, de facto, a sua personalidade de ideólogo, que não de mero executante da grande reestruturação, que se revela aqui. Será também, tout court, a

22 Cfr. Mariana Mora, ob. cit., pp. 144-145.

23 Relação Geral do Estado da Universidade, p. 137 (154).

${ }^{24}$ Efectivamente, ainda que se desconheça que tipo de mobiliário (se o tinha) possuia a galeria, não deixa de ser significativo registar a sua utilização como pinacoteca, seguramente na sequência da extinção das ordens religiosas, época em que a Universidade serve de depósito de quadros, como confirma um inventário de 1846, data em que aí se podiam ver 275 pinturas, pela maior parte desaparecidas (cfr. Manuel Augusto Rodrigues, "Relação dos quadros existentes no Paço das Escolas e na Capela da Universidade em 1846", Boletim do Arquivo da Universidade de Coimbra, vol. VI, Coimbra, 1984, pp. 348-363). 


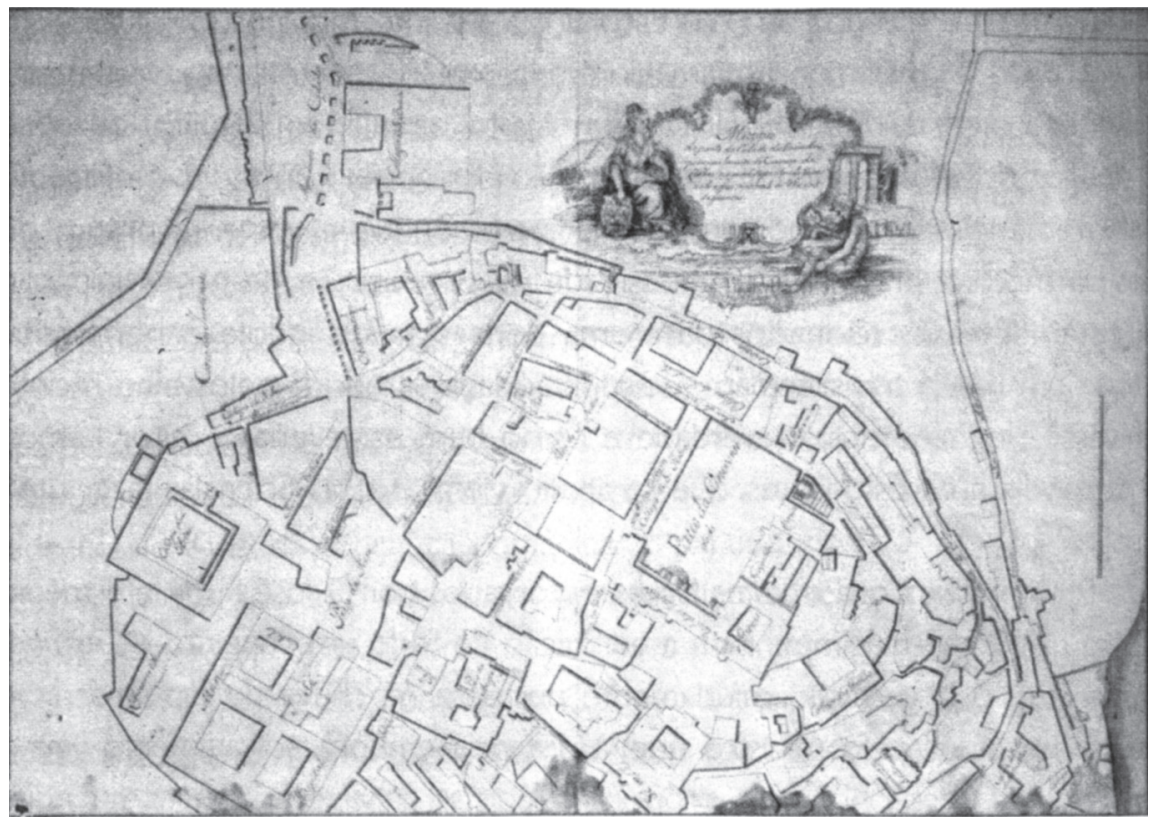

Desenhadores da Casa das Obras, planta da cidade alta com implantação dos edifícios pombalinos

(Museu Nacional de Machado de Castro, foto: José Pessoa, Divisão de Documentação Fotográfica do IPM) 
sua mesma personalidade. Na verdade, da concepção orgânica ao partido estético - mais conservador, menos ligado ao racionalismo pragmático da escola pombalina da reconstrução -, à própria autonomia administrativa com que escapa à tutela imposta pelo inglês (e por Pombal) na Casa das Obras, escolhendo livremente o tracista do plano que ideou ${ }^{25} \mathrm{ou}$, mesmo, se escusa ao cumprimento rigoroso dos planos arquitectónicos ideados pelo ministro, tudo neste empreendimento singular contribui para projectar luz sobre a figura, ainda hoje sinuosa, daquele que, no terreno, verdadeiramente seria o reformador.

A reconversão do Paço das Escolas e a sua integração na lógica visual da Nova Fundação, não constituíam, porém, a matéria central do investimento arquitectónico da Reforma. Esta, com efeito, ampliando significativamente o antigo espectro curricular com a criação das novas faculdades de Filosofia e Matemática, ao mesmo tempo que incrementava a vertente prática do ensino médico, produzira a necessidade da organização de novos espaços, directamente vocacionados para uma pedagogia de índole experimental e que em muito transcendiam a disponibilidade fornecida pelo velho recinto universitário. Sem eles, na verdade e como bem escreveria o reitor Lemos, "não podiam os Estudantes, que se applicassem ás ditas Sciencias fazer uteis progressos" 26 .

E, com efeito, os Estatutos Novos, outorgados por D. José I por intermédio do seu lugar-tenente, impunham a edificação de todo um conjunto de estabelecimentos, cuja gestação miudamente perpassa na chuva de diplomas sem cessar expedida pelo ministro que, à distancia embora, solicitamente velava

25 Esse homem, embora a documentação o não tenha ainda revelado (cfr. Maria de Lurdes Craveiro, Manuel Alves Macomboa, arquitecto da Reforma Pombalina da Universidade de Coimbra, Coimbra, Instituto de História da Arte, 1990, pp. 14-209), tudo indica que tenha sido Macomboa, artista de feição mais conservadora, homem de mão do reformador-reitor nas obras secundárias da Reforma e cujo papel na Casa das Obras adquiriria relevo crescente, em particular depois da partida de Elsden em 1777. Não obstante, carece de uma avaliação mais criteriosa o papel desempenhado por D. Francisco de Lemos na definição do partido estético da Reforma, realizados como eram os riscos por Elsden em Coimbra, antes de submetidos ao Marquês que, aliás, quase sempre os aprovaria.

26 Relação Geral, p. 5 (6). 
sobre a sua obra ${ }^{27}$. Como o próprio prelado se encarregaria de compendiar no seu circunstanciado relato do Estado da Universidade, seriam eles: "para o Ensino da Faculdade Medica, o Hospital, o Theatro Anatomico, e o Dispensatorio Pharmaceutico: para o Ensino da Mathematica, o Observatorio: E para o Ensino da Faculdade Philosophica, o Gabinete de Phisica Experimental, o Theatro da Historia Natural, o Laboratorio Chymico; e o Jardim Botanico". A estes se somava ainda a Imprensa, como pilar que evidentemente constituia de uma reforma cujo alcance pedagógico passava, desde logo, pela adopção de novos manuais ${ }^{28}$.

A universidade nova já não cabia, pois, no apertado perímetro da universidade velha. Os anos que se seguem, em particular os que medeiam entre 1773-77 (antes que o descalabro das finanças públicas impusesse uma drástica contenção de gastos) assistirão, assim, à conversão da zona alta da cidade num enorme estaleiro construtivo, centrado na Casa das Obras e meticulosamente regulado, à semelhança da reconstrução lisboeta, por um (aliás, idêntico) Regimento ${ }^{29}$. Aí pontificava Elsden a quem competia elaborar todas as traças, que o reitor remetia ao Marquês luxuosamente encadernadas em marroquim vermelho marcado, a ouro, das armas reais ${ }^{30}$. Desse modo, pois, iriam nascer os grandes imóveis que

27 De um modo geral, essa documentação encontra-se registada no conjunto de Livros de Alvarás, Cartas Régias, Provisões, Ordens e Avisos da Secretaria de Estado, que se conservam no Arquivo da Universidade de Coimbra, onde constituem o fundo designado de "Nova Fundação"

28 Cfr. Relação Geral, pp. 4-5 (5-6).

${ }^{29}$ Veja-se Pedro Dias, "O Regimento das Obras da Universidade de Coimbra ao tempo da Reforma Pombalina”, Boletim do Arquivo da Universidade de Coimbra, vol. VI, Coimbra, 1984, pp. 348.

30 Efectivamente, o investimento simbólico na Reforma passa também pelo luxo que rodeou a feitura dos desenhos, globalmente reunidos em dois riquíssimos albuns (um deles é pertença do Museu Nacional de Machado de Castro, onde possui o ${ }^{\circ}$ de inv. ${ }^{\circ}$ 2231/RB62, após o regresso, há poucos anos, de um longo depósito na Biblioteca Geral da Universidade de Coimbra; o outro, significativamente mais opulento, é propriedade dos herdeiros do falecido investigador de azulejaria eng. ${ }^{\circ}$ Santos Simões e foi publicado por Matilde Pessoa de Figueiredo de Sousa Franco, Riscos das Obras da Universidade de Coimbra, Coimbra, Museu Nacional Machado de Castro, 1983) tanto quanto pela escrupulosa omissão que neles uma vez mais se faz da velha Sapiência. A este respeito vale a pena transcrever um passo da correspondência de João Crisóstomo para D. Francisco de Lemos, onde surpreendemos ao vivo a própria reacção de Pombal, em Dezembro de 1775: "O contentamento, que Sua Ex. ${ }^{a}$ recebeu com a chegada do ten. ${ }^{\text {te }}$ Coronel Guilherme Elsden e com a aprezentação do formozo Livro dos prospectos, e Plantas das Obras Publicas dessa Universidade he inexprimivel, e so o $S$. ${ }^{\text {or }}$ João Pereira, que o prezenceou; o S. ${ }^{\text {or }}$ Conselheiro Seabra que se assombrou, o $S .{ }^{r}$ Cardeal que mostrou prazer grande; e o mesmo Elsden que se vio no cumulo do seu contentamento, o poderão bem dizer" (Manuel Lopes de Almeida, Documentos da Reforma Pombalina, vol. I, Coimbra, Por Ordem da Universidade, 1937, Doc.CXXII, pp. 215-216). 


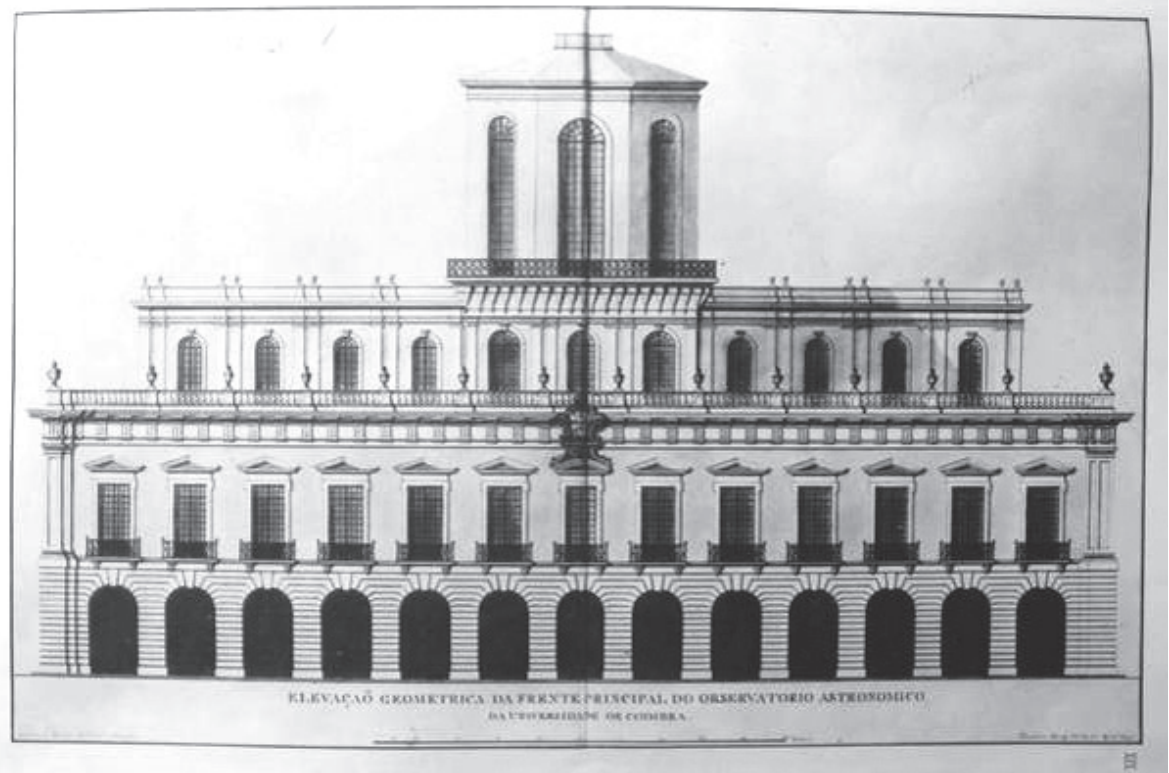

Guilherme Elsden, alçado principal do Observatório Astronómico (Riscos das Obras da Uníversidade de Coimbra, prop. part., foto: José Pedro Aboim Borges) 
haveriam de compor a civitas sapientice pombalina: o Museu de História Natural, produto da radical transfiguração do complexo jesuítico do antigo Colégio de Jesus, para o efeito incorporado no perpétuo domínio da Universidade e que abrigava, além do competente gabinete de História Natural, o de Física e os institutos ligados à Faculdade de Medicina (o Hospital e os respectivos Teatro Anatómico e Dispensatório Farmacêutico); o Laboratório Químico, fronteiro e de igual modo erguido à custa das antigas cozinhas dos apóstolos; o Observatório, em benefício do qual se derrubaria o castelo, ao mesmo tempo incorporado; o Jardim Botânico, nas imediações do aqueduto, ocupando parte da cerca de S. Bento e da dos Marianos, rapidamente disponibilizadas pelos respectivos padres; a Imprensa, enfim, instalada no claustro da antiga Sé, entretanto transferida para a devoluta igreja da extinta Companbia ${ }^{31}$.

Sob o impacte dos novos edifícios, a urbe transfigurava-se mas, muito especialmente, reconvertia-se, repensando as suas relações tradicionais. A Universidade transpusera os muros da alcáçova, é certo, mas a cidade do saber fechava-se agora sobre si, olimpicamente, entre os muros da acrópole, deliberadamente quebrando o íntimo convívio que a malha dos colégios renascentistas mantivera com a cidade antiga. De resto e mau grado as intervenções (pontuais) de verdadeiro urbanismo, como a nova praça que iria surgir entre o Laboratório e o Museu, a regularização do Largo da Feira e da envolvência do Observatório, a libertação do entorno do Paço das Escolas ou, mesmo, a monumentalização da couraça Sul, principal acesso ao recinto universitário, desembocando no Observatório

31 Cfr. Maria de Lurdes Craveiro, "Guilherme Elsden...”, pp. 511-519; Anabela Bento, "A construção do edifício pombalino do Museu de História Natural da Universidade de Coimbra", Actas do Colóquio A Universidade e a Arte, 1290-1990, Coimbra, Instituto de História da Arte, 1993, pp. 177-219; Conceição Amaral, "Novos dados para a construção da Imprensa da Universidade”, ibidem, pp. 221-251; Maria Teresa Cardoso Duarte, "Alguns dados acerca da construção do Jardim Botânico da Universidade de Coimbra", ibidem, pp. 403- 441 e Luísa Trindade, "A Reforma Pombalina", Monumentos, $\mathrm{n}^{\circ} 8$, Lisboa, 1998, pp. 35-39). 

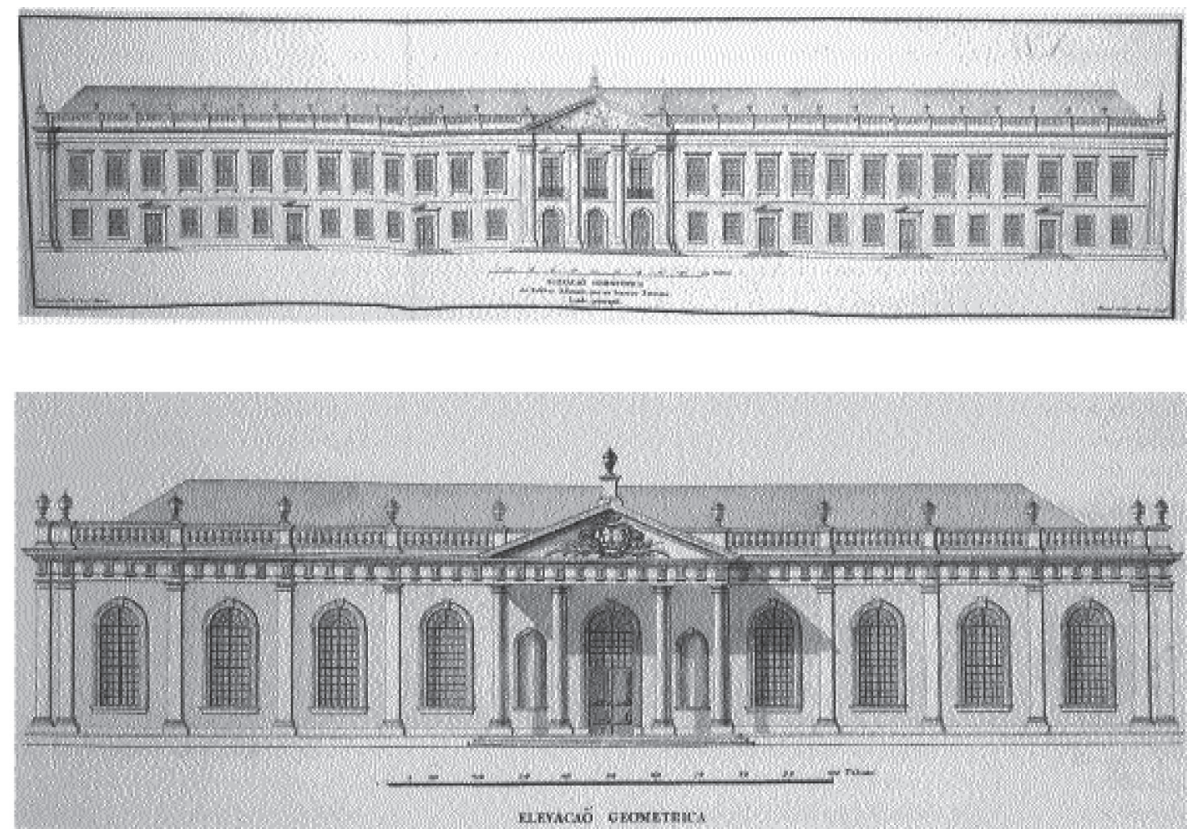

Guilherme Elsden, alçado principal do Museu de História Natural (Riscos das Obras da Universidade de Coimbra, prop. part., foto: José Pedro Aboim Borges)

Guilherme Elsden, alçado principal do Laboratório Químico (Riscos das Obras da Universidade de Coimbra, prop. part., foto: José Pedro Aboim Borges) 
Astronómico e que chegava a incluír frentes de rua ${ }^{32}$, a prática construtiva da refundação parecia nortear-se, essencialmente, por dois objectivos principais: eliminar os vestígios visuais da antiga preponderância jesuítica e dotar a cidade de uma arquitectura de prestígio que, simultaneamente, reformasse a sua própria imagem.

Efectivamente, os diversos estabelecimentos pombalinos, riscados num neo-palladianismo inteligente, inovador no panorama nacional e onde a unidade conceptual saberia, não obstante, evitar a monotonia das soluções, distinguem-se, tanto ao nível do plano como dos alçados, pelo mesmo racionalismo pragmático que norteara a própria obra da Reformação ${ }^{33}$. Não conformam, porém, um genuíno campus, a exemplo do que noutras cidades universitárias sucedia e, mesmo, de certo modo se realizara na Coimbra renascentista; antes se disseminam pelo velho casco de configuração medieval, numa recorrente ilustração da generosidade esclarecida do poder de que constituíam directa emanação, opção que o conjunto Museu-Laboratório não desmente e que as evidentes razões de natureza técnica (disponibilidade do edifício jesuíta; inutilidade do antigo castelo e aparente adequação do local às observações astronómicas; possibilidade de lançar mão das instalações da antiga catedral pela sua transferência para a sumptuosa igreja dos inacianos) porventura não explicarão completamente.

Nesta vontade de impor à malha urbana, que fora o secular cenário do execrado tempo obscurantista, a marca indelével do novo poder, residirá também a razão do ritmo plástico adoptado na concepção dos diversos edifícios, definidor de uma evidente escala de valores, deliberadamente assumida e de incontornável significado num contexto onde os critérios de racionalidade e rigor abrangiam também e muito particularmente

32 Cfr. Walter Rossa, "A Cidade Portuguesa", Paulo Pereira (dir. de), História da Arte Portuguesa, vol. III, Lisboa, Círculo de Leitores, pp. 307-308. Sobre o Largo da Feira veja-se Teophilo Braga, História da Universidade de Coimbra, Lisboa, Academia Real das Sciencias, 1898, vol. III, p. 438 e 505. Quanto à criação de uma área de protecção ao Paço das Escolas é o próprio D. Francisco de Lemos que relata: "Separei os Paços dos torpes, e insignificantes Edificios Velhos, que com eles pegavam: Mandei formar huma Muralha, que aliviando a Imprensa do Monte de terra, que a sepultava, sustenta o pezo da terra; forma hum Terreno agradavel sobre a Cidade; e por ella se da Communicação dos Paços á Imprensa” [Relação Geral, p. 137 (155)].

33 Cfr. Luísa Trindade, ob. cit., pp. 54 e 57. 

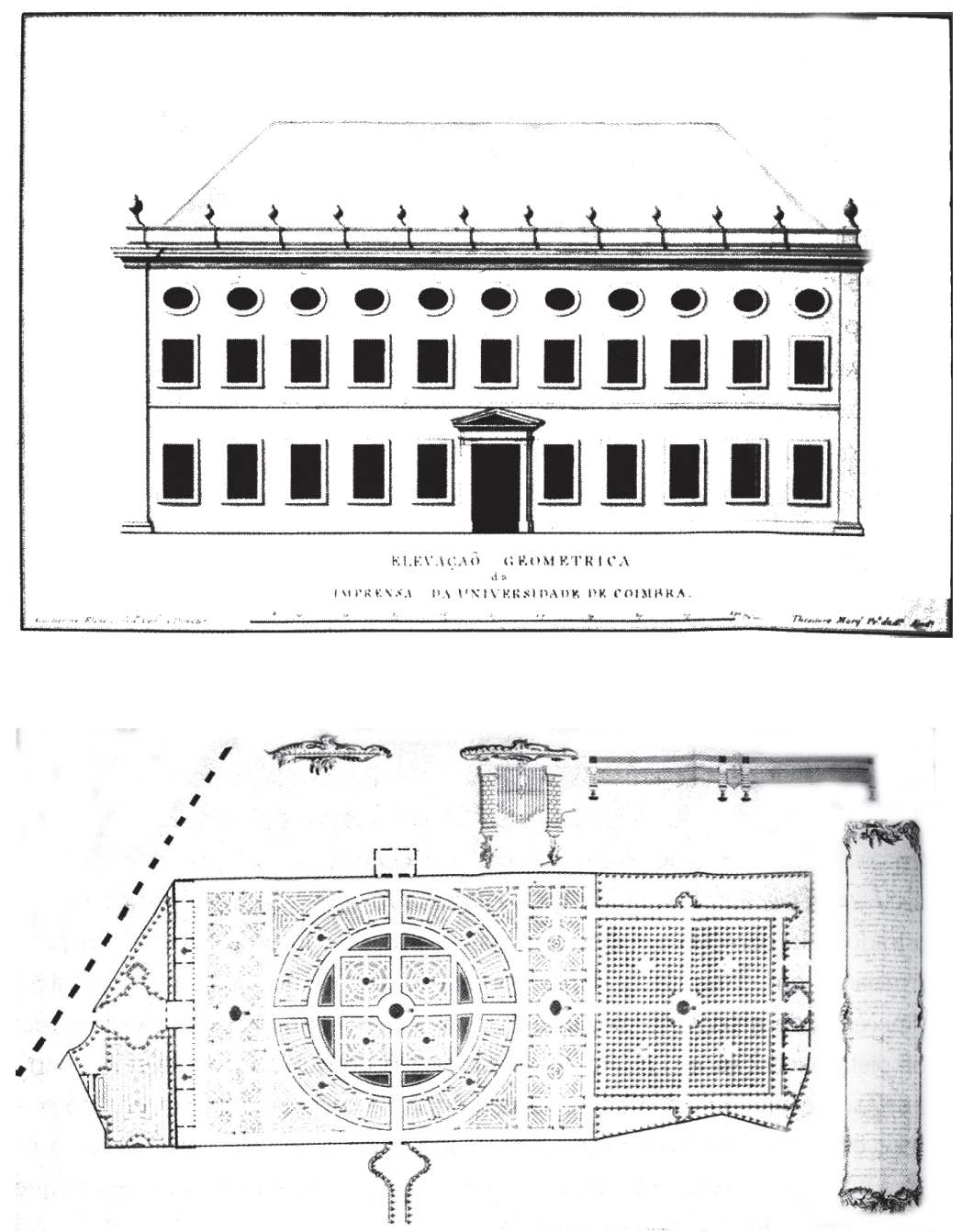

Guilherme Elsden, alçado principal da Imprensa

(Riscos das Obras da Universidade de Coimbra, prop. part., foto: José Pedro Aboim Borges)

Júlio Mattiazzi, planta do Jardim Botanico

(Riscos das Obras da Uníversidade de Coimbra, prop. part., foto: José Pedro Aboim Borges) 
as questões ligadas a gastos e administração. De facto, o conjunto dos estabelecimentos pombalinos dispõe-se de acordo com uma sequência rítmica onde, ao tempo forte que representa o inacabado mas ostentoso Observatório - ponto estratégico de intersecção no percurso entre a couraça e o Paço das Escolas e, inquestionavelmente, pièce d'bonneur de todo o conjunto - se segue um tempo médio, ilustrado pelo complexo, majestoso mas sóbrio, do Museu e Laboratóro, para terminar, já em clima de evidente contenção formal, nos restantes institutos: a Imprensa, de prospecto elegante mas severo e o Jardim Botânico, obra cuja completa execução em muito transcenderia o consulado pombalino e onde se seguiria o plano de Mattiazzi, na sequência da recusa pelo Marquês do primeiro e luxuoso risco, elaborado por Elsden sob a orientação dos professores Ciera e Vandelli e reputado mais próprio para "Ostentação de Princepes" que para "Jardim de Estudo de rapazes" 34 .

Ao recusar o partido do campus, fechado sobre si, a cidade do saber apostava, contudo, uma vez mais na funcionalidade. De facto, a eficácia dessa segunda reconstrução que, em Coimbra, se levava a efeito sobre as ruínas do que fora o império pedagógico jesuíta, pulverizado pelo terramoto legislativo pombalino, dependia verdadeiramente desse processo de apropriação da malha urbana pela Universidade refundada. Por isso os edifícios da Reforma contaminam a urbe e dela tomam posse, numa relação explícita de poder que se ostenta a cada encruzilhada. Nesse sentido, os estabelecimentos universitários não constituíam somente emanações do poder real que havia promovido a sua construção - eram antes metáforas desse mesmo poder, como eles laico, racional e, sobretudo, omnipresente. Donde o carácter civil escrupulosamente observado no seu tratamento plástico; donde, por fim, o código simbólico que deliberadamente ostentam.

${ }^{34}$ Cfr. Manuel Lopes de Almeida, ob. cit., vol. I, Doc.LXV, p. 106. Sobre este assunto, veja--se Maria Teresa Cardoso Duarte, ob. cit., p. 418. 
Efectivamente, não ficaria sem reparo que, "de 1724 para cá, a Universidade parece ter esquecido a Sapiência"35. Assim, na verdade, suprimida no prospecto da Biblioteca Joanina em benefício das armas reais, a velha insígnia universitária faria a sua derradeira aparição no frontespício da Via Latina: justamente por ser a insígnia da universidade velha. Novamente fundada, a antiga escola convertera-se, de facto e no mais extenso sentido da expressão, na Universidade Real. Régios seriam, pois, os Estatutos Novos, por isso marcados das armas do monarca, como régios seriam os novos estabelecimentos científicos (as Reaes Obras da Universidade ${ }^{36}$ ) cujas traças, ricamente acondicionadas em brochuras ornadas do escudo real, o próprio Pombal pessoal e escrupulosamente analisara - o Real Observatório; o Real Museu de História Natural, com os seus Reais Gabinetes; o Real Laboratório Químico; o Real Jardim Botânico; a Real Imprensa.

Seria, assim, o escudo régio, distintivo da natureza estatal da escola nova, laboriosamente edificada, pedra a pedra, pelo reformador ministro e pelo reformador-reitor e não a antiga representação simbólica da instituição que juridicamente se suprimira com a suspensão dos Estatutos Velhos, a distinguir os novos edifícios, como signo heráldico e sinal de posse. Assim, pois, na cornija do opulento Observatório, como no frontão (não realizado ${ }^{37}$ ) do Laboratório Químico; assim, tudo leva a crer, no

35 A. G. da Rocha Madahil, "A insígnia da Universidade”, p. 445. A data de 1724 corresponde à da representação da Sabedoria na chamadas "Escadas de Minerva" e o facto de ser a última utilização da emplemática personagem registada pelo historiador resulta da sua atribuição da Via Latina ao reitorado de Nuno da Silva Teles (I), contemporânea, por conseguinte, das grandes obras de remodelação dos Gerais levadas a efeito pelo prelado entre 1698 e 1702 e já então esclarecidas por Vergílio Correia, no seu estudo "Obras antigas da Universidade", Obras, vol. I, Coimbra, Por Ordem da Universidade, 1946, pp. 146-151, donde resuta atribuír também a respectiva Sapiência ao escultor Claude de Laprade que V.C. justamente no mesmo local identificara (cfr., idem, ibidem, pp. 437-441).

36 Cfr. Manuel Lopes de Almeida, ob. cit., vol. I, Doc.LXII, p. 100.

37 Inconcluso, o edifício receberia no século XIX o deselegante remate que actualmente ostenta (cfr. Vergílio Correia, e A. Nogueira Gonçalves, Inventário Artístico de Portugal Cidade de Coimbra, Lisboa, Academia Nacional de Belas-Artes, 1947, p. 109a). 


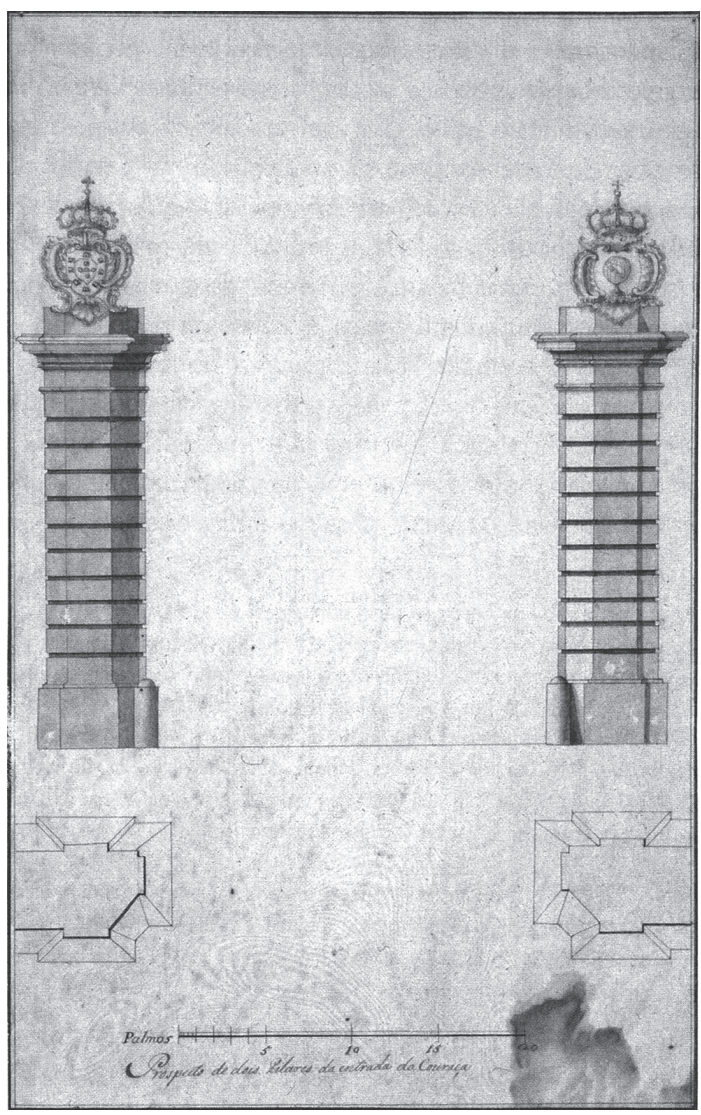

Guilherme Elsden (?), alçado dos pilões monumentais para a Couraça de Lisboa (Museu Nacional de Machado de Castro, foto: José Pessoa, Divisão de Documentação Fotográfica da DGPC) 
Jardim Botânico ${ }^{38}$; assim, ainda, se não no alçado da Real Imprensa, ao menos nas obras saídas dos seus prelos ${ }^{39}$. A prevista monumentalização da Couraça de Lisboa, só muito parcialmente realizada, assinalava o ingresso na cidade universitária pela erecção, junto a Santo António da Estrela (cuja fachada de igual modo se reformava), em substituição da Porta de Belcouce, de dois imponentes pilões apilastrados, de silharia de junta fendida, rematados por escudos coroados, ostentando um a heráldica régia e o outro a esfera armilar, ícone de significado ambíguo, a um tempo real e científico ${ }^{40}$. E o mesmo se passaria, pelo tempo fora, nos mais simbólicos empreendimentos universitários, seja na porta nova que Macomboa realizou, em 1780, ao amputar-se a Capela universitária para propiciar acesso às repartições ${ }^{41}$ seja, mesmo, em publicações como

38 As obras do Jardim Botânico prolongar-se-iam no tempo por bastantes anos o que levaria a uma complexa sucessão de opções arquitectónicas. Não obstante, o projecto - não assinado mas, decerto, da mão de Júlio Mattiazzi, que assina o do Jardim - para as estufas, incorporado no sumptuoso album atrás referido intitulado Riscos das Obras... e publicado por Matilde Sousa Franco (ob. cit., p. 5 e est. XXX) ostenta as armas reais, tal como outro risco, mais simplificado, elaborado por Macomboa em 1791 e conservado no Museu Machado de Castro, (cfr. Maria de Lurdes Craveiro, Manuel Alves Macomboa..., p. 34 e fot. 12), outro tanto se verificando, ainda, na grade de ferro do portão principal, colocada em 1844, ano em que, efectivamente, seria concluída a estrutura arquitectónica, que começara a erguer-se no ano anterior (Vergílio Correia e A. Nogueira Gonçalves, ob. cit., p. 110a), porém desenhada por José do Couto em 1818 (cfr. Luísa Trindade, "José do Couto, arquitecto titular da Universidade de Coimbra. 1824-1829”, Actas do Colóquio A Universidade e a Arte, 1290-1990, Coimbra, Instituto de História da Arte, 1993p. 68). Contudo, o confronto do portal e cerca do Jardim Botânico com a guarda prevista para a muralha monumentalizada da Couraça de Lisboa, cujo desenho, elaborado na Casa das Obras pela equipa de Elsden, se conserva no Museu Nacional de Machado de Castro (Inv. 2937/DA 20), faz suspeitar, atenta a semelhança das urnas, que José do Couto reutilizaria desenhos (e, por conseguinte, opções e programas) definidos ao tempo da Reforma.

39 "A Imprensa usou nas suas edições, quási sempre, as armas do Reino, como Real Imprensa que era; só no presente século deu preferência às insignias universitárias” (A. G. da Rocha Madahil, ob. cit., p. 448).

$40 \mathrm{O}$ projecto, elaborado na Casa das Obras, seguramente sob a direcção de Elsden, conserva-se no Museu Nacional de Machado de Castro (Inv. 2899/DA 21 e 2872/DA 19). Quanto à esfera armilar, incorporada na heráldica régia portuguesa desde D. Manuel I, é curioso notar que a sua primeira aparição num programa universitário coincide com a primeira utilização das armas reais - o programa decorativo da Biblioteca Joanina onde, com efeito, a reconhecemos no estandarte da trombeta de um dos anjos-fama que enquadram o escudo régio sobre o retrato de D. João V, apresentando o outro o mocho da ciência.

${ }^{41}$ Veja-se Maria de Lurdes Craveiro, ibidem, p. 20. Aliás, constitui também consequência da Reforma, ainda no âmbito do Paço das Escolas, a substituição pelas armas reais do escudo apostólico que ornava o portal do (até aí) Sacro, Pontifício e Real Colégio de S. Pedro (cfr. Manuel Lopes de Almeida, ob. cit., vol. I, Doc.CXV, p. 196). 
o indice alphabetico dos estudantes, anualmente editado a partir de 1800, ou o ritual Annuário, ao qual, como já foi dito, "se deve reconhecer carácter de publicação oficial" 42 . Assimilada ao Estado, de que constituía emanação, a Universidade fazia, assim, sua a sua imagem.

É, de facto, a presença contínua e recorrente das armas do Reino no prospecto urbano que, mais do que tudo, confere à cidade do saber o seu carácter de cidade do poder. Universidade realmente régia, não já na antiga acepção de corporação privilegiada que tão cara the fora, mas nessa outra, moderna, de prolongamento do poder central, a velha escola submetia-se, pois, com docilidade insuspeitada à nova função que lhe era cometida. Fazia-o para sobreviver. E nisso demonstrava, afinal, uma vez mais, a sua atávica e secular sabedoria.

42 A. G. da Rocha Madahil, ob. cit., p. 422. Convém, todavia, notar, que, na ausência de qualquer referência, nos Estatutos pombalinos, à insígnia e selo universitários (reforçada pela Carta Régia de 05.11.79 que estabelecia qua a Universidade se regulasse pelos antigos Estatutos em tudo o que pelos novos não fosse determinado em contrário) se instalaria, numa instituição com a tradição burocrática da Universidade de Coimbra, uma tendência para a perpetuação das antigas práticas, desse modo levando à utilização ininterrupta, em diplomas reitorais e cartas de curso, de selos com a tradicional insígnia. Sem prejuízo de o actual selo, da autoria de António Augusto Conçalves, constituír, na forma como no espírito, uma obra de carácter verdadeiramente revivalista, a antiga insígnia só viria realmente a ser posta em causa duas vezes: uma em 1890, pelo lente de Matemática Rocha Peixoto, a cujo escrúpulo piedoso repugnava a presença da pseudo-Minerva no distintivo universitário e outra em 1910, protagonisada pelo reitor Manuel de Arriaga, cujo prurido republicano, não menos observante, se não conformava com a conservação da antiga empresa per me reges regnant...Em conformidade, um despacho ministerial de 16 de Outubro do mesmo ano, mais zeloso que a legislação pombalina, imporia uma reforma do antiquíssimo símbolo, determinando a abolição da coroa real, da cruz do ceptro e da subversiva legenda e cujas sequelas, na verdade, parecem durar ainda (cfr. Idem, ibidem, pp. 404, 427-429 e 420-421). 


\section{Série Investigação}

Imprensa da Universidade de Coimbra

Coimbra University Press

2014

- U

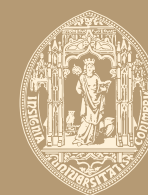

C •

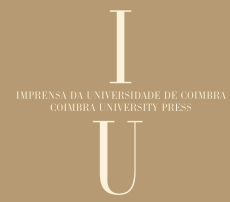

